\title{
ANALYSIS OF THE POTENTIAL AND OPPORTUNITIES FOR AGRICULTURAL PRODUCTION AND AGRICULTURAL PROCESSING IN UKRAINE
}

\author{
Svitlana Kushnir ${ }^{1}$, Serhii Zasoba²
}

\begin{abstract}
The objective of the article is to study the possibilities of agricultural production and agricultural processing and search for the prospects of development of the industry of Ukraine. Methodology. The following analyses are carried out: profitability and cost-effectiveness (rate of return) of the agricultural products, the level of consumption of basic food products in Ukraine, availability of agricultural machinery at agricultural enterprises, the structure and growth rate of purchase of agricultural machinery at agricultural enterprises of Ukraine. Results. It is proved that a low level of profitability in the agricultural sector is a significant violation of price parity - there is a deterioration in the ratio of the prices of agriculture producers for sold products, and prices for acquired industrial goods, and for the services of commercial and technical purpose, i.e. there is a situation of non-conformity of revenues and costs of agricultural production. It should be noted that the level of the development of the agricultural complex, first of all, is determined by the quality and volume of food consumed by the population. Practical implications. During the country's independence, the profitability of production of all major products has decreased significantly and negative trends are observed. Comparing the data of 2019 with 1990, we can see that part of the profitable production has transferred to the unprofitable. The analysis of the dynamics of consumption of major food groups over the past two decades shows that for the period from 2000 to 2014 there was an increase in consumption of milk and dairy products by $12 \%$; meat and meat products by $65 \%$; eggs by $86.7 \%$; potatoes by $4 \%$, vegetables and melons by $60.5 \%$; fruits, berries and grapes by $78.5 \%$; fish and fish products by $32.1 \%$; oils by $39.4 \%$. During this period, there was a decrease in the positions of bread and bread products by $13 \%$ and sugar by $1.4 \%$. Value/originality. The low intensity of the agricultural sector of Ukraine is largely due to the neglect of the requirements of agricultural machinery and production technology. It is important to apply the required amount of mineral fertilizers, which is one of the important technological requirements for growing crops. Therefore, the effective development of this industry requires a modern, effective and scientifically sound financing program by attracting investment and soft loans.
\end{abstract}

Key words: agricultural products, agricultural processing, analysis of the dynamics of consumption, households.

JEL Classification: E42, Q01

\section{Introduction}

The role of effective, high-yielding and dynamically growing agricultural sector as a systemforming industry is to provide the population with high-quality food products, to form the country's export potential, to ensure food security of the state and high competitiveness of the national economy. Escalation of the situation on the world food market, liberalization of foreign trade relations, growth of the world and domestic food products

\footnotetext{
Corresponding author:

${ }^{1}$ Zaporizhzhia National Universty, Ukraine.

E-mail: SvitlanaAK@ukr.net

ORCID: http://orcid.org/0000-0002-1410-1887

${ }^{2}$ Black Sea Research Institute of Economy and Innovation, Ukraine.

E-mail: Zasobasn@gmail.com

ORCID: http://orcid.org/0000-0001-6358-921X
}

prices require the search for perspectives for the agriculture development and improvement of its managerial mechanisms as a priority.

It should be noted that households are dominated by technologies based on the use of manual labor, with low use of genetic potential of cultivated plant varieties, animal breeds, low level of foodstuff and its quality, weak material and technical base of the industry, lack of conditions for industry development based on resource 
saving technologies, which is determined by the low competitiveness of small scale production on a market scale.

Material and technical support, and logistics are the basis for production, processing of agricultural products and bringing it to consumers, as it provides increased efficiency of processes that take place in agro-industrial enterprises. Acceleration of scientific and technological progress contributes to the growth of competition in the world market and proves the importance of introduction of new means of production. A special place in this sector is given to tractor and agricultural machinery, the main centers of which are Berdiansk, Dnipro, Kyiv, Kolomyia, Nizhyn, Novohrad-Volynskyi, Odesa, Ternopil, Uman, Kharkiv and Kherson (Sabluk, 2011).

Within the conditions of limited resources the issues of increasing the efficiency of resource use in the agricultural sector of Ukraine become especially important. In this regard, the purpose of this study is the analysis of possibilities of agricultural production and agricultural processing and search for prospects for the development of this industry in Ukraine.

\section{Analysis of profitability and cost- effectiveness of agricultural products}

Today, agricultural production in Ukraine is a low-profit industry; its profitability is about $30 \%$. About $20 \%$ of agricultural enterprises are unprofitable, and the profitability of production of most types of agricultural products is insufficient to ensure expanded reproduction (Table 1).

During the country's independence, the profitability of production of all major products has decreased significantly, and negative trends are observed. Comparing the data of 2019 with 1990, we can see that part of the profitable production has become unprofitable. Thus, the biggest drop in profitability is observed in the production of beef and poultry, as well as eggs and sugar beets. The cost-effectiveness of grain production in 2019 was only $4 \%$ of 1990 , although, despite the decline, it still remains profitable. According to the analyzed indicators, the highest position is occupied by the profitability of dairy production $-64 \%$ of the indicator of 1990. The analysis of profitability of the last decade shows the transition to the category of unprofitable and the worst profitability of egg production (2.3 times down), sugar beet (1.9 times), but compared to 2010 there is an increase in profitability of pork production (by $40 \%$ ) and dairy products (by 15\%). Unfortunately, comparing 2019 with 2018, we have an increase in the loss of cattle for meat (by 53\%), sugar beets (by 35\%), as well as the transition from profitable to unprofitable poultry production for meat and eggs (profitability falling in more than 5 times).

An important reason of the low profitability of agricultural sector is a significant violation of price parity - there is a deterioration in the ratio of the prices of agriculture producers for sold products, and prices for acquired industrial goods, and for the services of commercial and technical purpose, i.e. there is a situation of non-conformity of revenues and costs of agricultural production. It should be noted that the level of development of the agricultural complex is primarily determined by the quality and volume of food consumed by the population. To determine the role of the social component of the agricultural sector, it is advisable to analyze the consumption of major food groups.

\section{Assessment of the level of food consumption}

The analysis of the dynamics of consumption of major food groups over the past two decades shows that for the period from 2000 to 2014 there was an increase in consumption of milk and dairy products by $12 \%$, meat and meat products by $65 \%$, eggs by $86.7 \%$, potatoes by $4 \%$, vegetables and melon crops - by $60.5 \%$, fruits, berries and grapes by $78.5 \%$, fish and fish products - by $32.1 \%$, oil by $39.4 \%$. During this period there was a decrease in the positions of bread and bread products by $13 \%$ and sugar - by $1.4 \%$ (Table 2 ).

From 2014 to 2018, the level offood consumption has unstable trends. This situation characterizes the instability of economic development and the accelerated level of inflation in Ukraine (Kushnir S., 2017).

We analyzed the consumption of bread per person. According to the results, it was found that it decreased by $9 \mathrm{~kg}$ (by $8.3 \%$ ); milk - by 25.1 liters (11.3\%); eggs - by 35 pcs. (11.3\%); sugar by $6.5 \mathrm{~kg}$ (by $17.9 \%$ ); potatoes - by $1.6 \mathrm{~kg}$ (by $1.1 \%$ ); meat and meat products - by $1.3 \mathrm{~kg}$ (by $2.3 \%$ ); oil - by 1.2 liters (by 9.2\%). The increase in consumption occurred only in fruit and berry products - by $5.5 \mathrm{~kg}(10.5 \%)$; fish and fish products - by $0.7 \mathrm{~kg}$ (by $6.3 \%$ ) and vegetables by $0.7 \mathrm{~kg}$ (by $0.4 \%$ ). It should be noted that the unstable consumption of potatoes, vegetables, fruits and berries is 


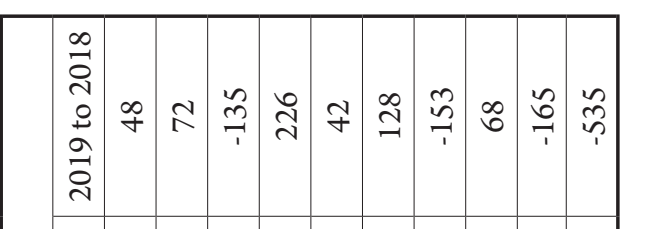

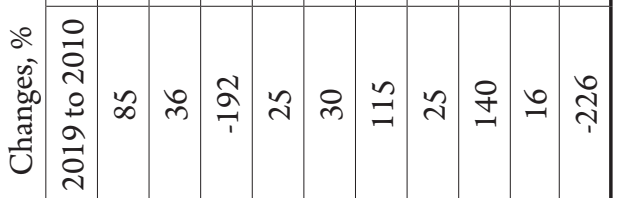

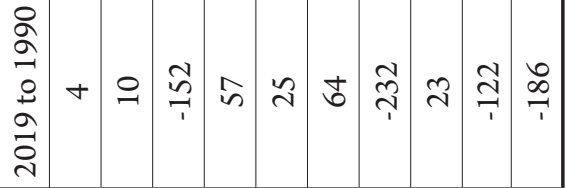

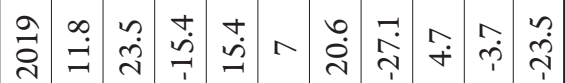

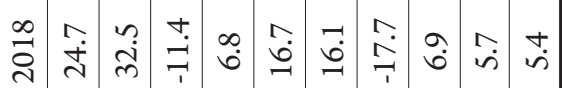

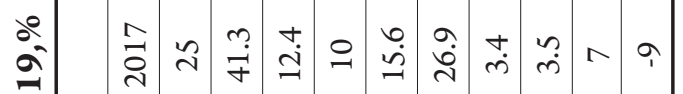

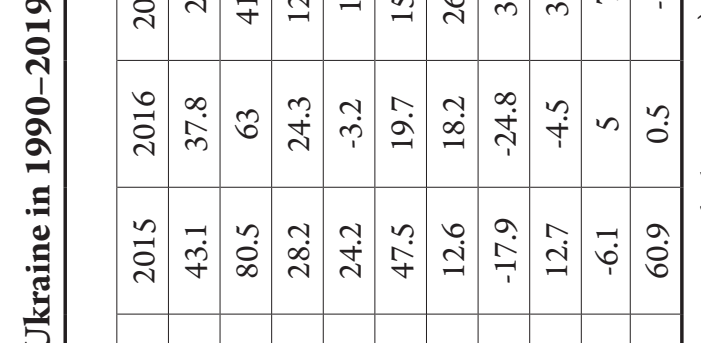

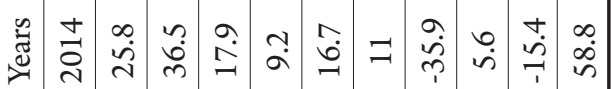

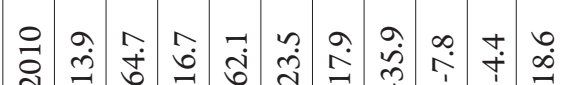

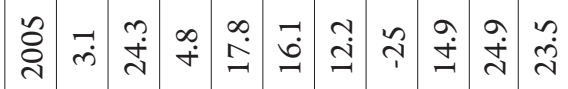

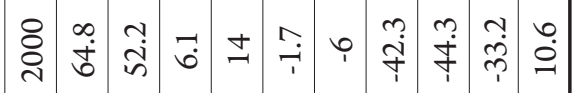

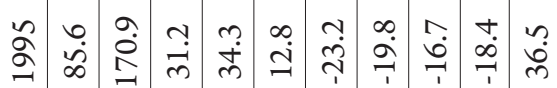

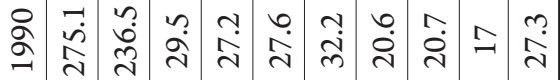

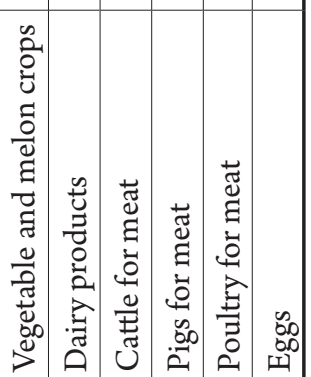

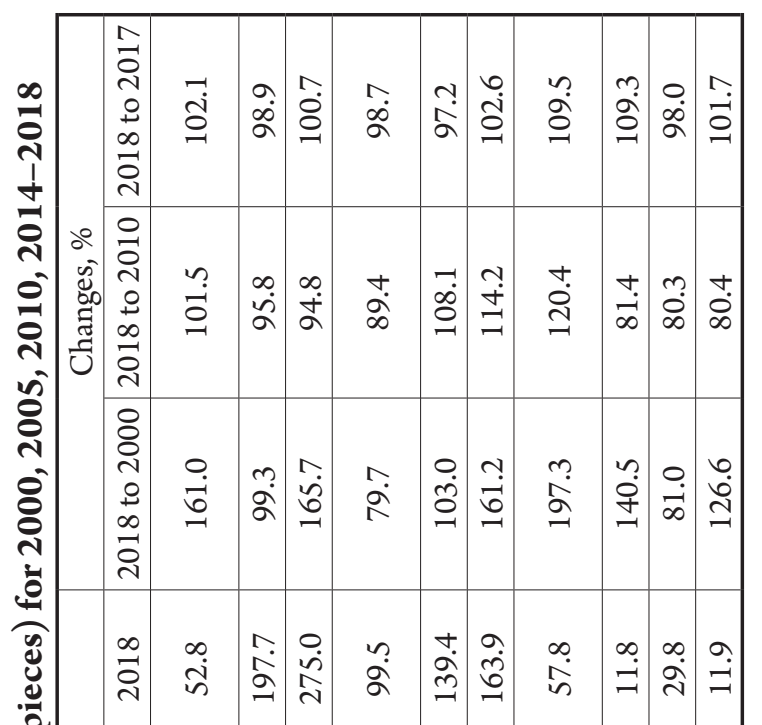

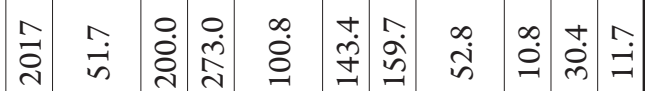

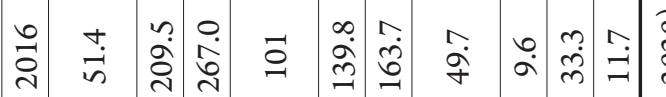

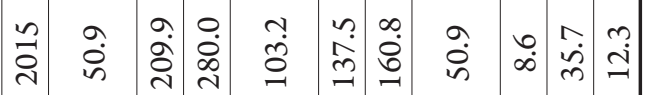

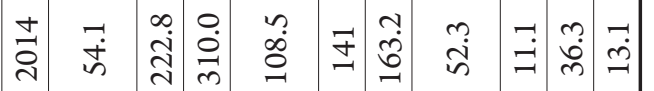

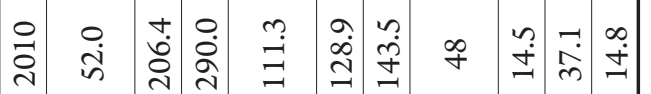

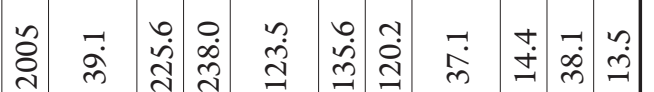

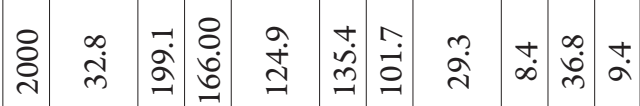

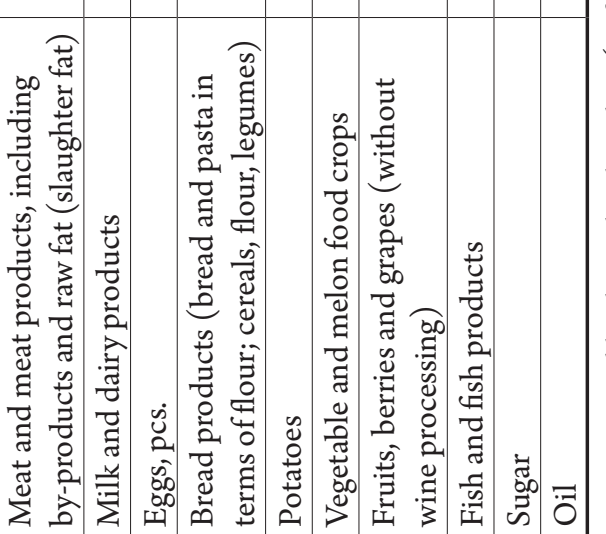


a corresponding sign of the volume of their production in households and the seasonality of price formation for these categories.

But at the moment, Ukraine's agriculture does not satisfy $100 \%$ of the country's food needs. Unfortunately, part of the range of products that are in demand from consumers and can be produced in-house, is imported from abroad.

The analysis of the share of the value of fixed assets in the agricultural sector among other sectors of the economy shows its insignificant weight both in $2000(11.7 \%)$ and its almost 10 times decrease over the last twenty years. It should be noted the significant degree of depreciation and obsolescence of fixed assets and the improper level of their renewal.

The vast majority of medium and small producers are not provided with sufficient agricultural machinery. And the available equipment is worn out morally and physically, which does not contribute to increasing productivity and obtaining consistently high business results.

One of the factors that determine the sustainability of the resource potential of agriculture is the level of its technical and technological support. The number of tractors in agricultural enterprises in the country in the period 2014-2017 decreased by $1.2 \%$, and since 2011 - by more than $13 \%$. And the situation is the same not only for tractors, but also for other types of agricultural machinery.

Thus, in the same period the number of combine harvesters decreased by $1.5 \%$, corn harvesters - by $14.6 \%$, forage harvesters - by $13.6 \%$, flax harvesters - by $31.1 \%$. The largest increase in the number of machinery during this period was observed in haymakers - by $36.4 \%$, tractor trailers - by $25 \%$, gross reapers - by $14.1 \%$, sprinklers $-13.5 \%$.
The analysis of agricultural machinery in farms showed that the largest share is made by potato planters $-47.1 \%$, potato harvesters $-37 \%$, grain harvesters $-33.9 \%$, drills $-31.9 \%$, tractors $-28.8 \%$, gross harvesters $-28.5 \%$, hay mowers $-26.1 \%$.

The smallest share is represented by flax harvesters $-4.2 \%$, cattle feed distributors $-5.7 \%$, manure conveyors $-6.3 \%$, milking machines and devices $-9.2 \%$. That is, farms specialize more in crop production, such as cultivation of potatoes and cereals. The commissioning of new storage facilities for vegetables and fruits remains a problem issue.

\section{Analysis of the availability of agricultural machinery}

Let us analyze the availability of agricultural machinery in more detail in 2018-2019 (Table 3). Analysis of the data in Table 3 shows that most of the field equipment belongs to households, agricultural enterprises own more combines, more than a third of which are owned by farms.

If we analyze the growth rate over the past two years (Table 4), we can see that in general the number of equipment in all positions has decreased, mostly for tractors and plows, and it is due to a decrease in the number of equipment in households. Comparing the indicators of technical support of agricultural enterprises and households, it should be noted that the latter concentrates a larger number (45\%) of tractors and mini-machinery. But, as a rule, the equipment, which is in households of the population, is the equipment, which has been in use of large agricultural enterprises, and has almost completely used resource potential. Similar trends characterize the dynamics of energy capacity and electricity consumption in agriculture in 2011-2017.

Table 3

Availability of agricultural machinery in agricultural enterprises of Ukraine 2018-2019, pcs.

\begin{tabular}{|c|c|c|c|c|c|c|c|c|}
\hline \multirow{3}{*}{$\begin{array}{l}\text { Types of } \\
\text { equipment }\end{array}$} & \multicolumn{4}{|c|}{2018} & \multicolumn{4}{|c|}{2019} \\
\hline & \multirow[b]{2}{*}{ Total } & \multicolumn{3}{|c|}{ Including } & \multirow[b]{2}{*}{ Total } & \multicolumn{3}{|c|}{ Including } \\
\hline & & $\begin{array}{l}\text { Agricultural } \\
\text { enterprises }\end{array}$ & $\begin{array}{l}\text { Including } \\
\text { farms }\end{array}$ & $\begin{array}{l}\text { Farms of the } \\
\text { population } \\
\text { (households) }\end{array}$ & & $\begin{array}{l}\text { Agricultural } \\
\text { enterprises }\end{array}$ & $\begin{array}{l}\text { Including } \\
\text { farms }\end{array}$ & $\begin{array}{l}\text { Farms of the } \\
\text { population } \\
\text { (households) }\end{array}$ \\
\hline Tractors & 377306 & 128697 & 40053 & 248609 & 310607 & 130529 & 41783 & 180078 \\
\hline Combines & 42925 & 26287 & 9636 & 16638 & 41110 & 26524 & 9986 & 14586 \\
\hline Sowing machines & 195922 & 65070 & 22898 & 130852 & 189013 & 66511 & 24322 & 122502 \\
\hline Plows & 351830 & 49924 & 18431 & 301906 & 310249 & 51447 & 19654 & 258802 \\
\hline Cultivators & 210156 & 70505 & 24120 & 139651 & 192660 & 71633 & 25309 & 121027 \\
\hline Harrows & 524819 & 161129 & 34251 & 363690 & 502567 & 160004 & 35660 & 342563 \\
\hline
\end{tabular}

Source: created by the author based on (Ofitsiini dani z saitu Derzhavnoi sluzhby statystyky Ukrainy) 
Table 4

Structure and growth rate of purchase of agricultural machinery in agricultural enterprises of Ukraine in 2018-2019, \%

\begin{tabular}{|c|c|c|c|c|c|c|c|c|c|c|}
\hline \multirow[b]{3}{*}{$\begin{array}{l}\text { Types of } \\
\text { equipment }\end{array}$} & \multicolumn{3}{|c|}{2018} & \multicolumn{3}{|c|}{2019} & \multicolumn{4}{|c|}{ Growth rate, $\%$} \\
\hline & \multirow[b]{2}{*}{ 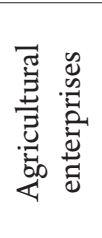 } & \multirow[b]{2}{*}{ 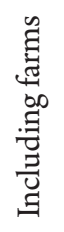 } & \multirow[b]{2}{*}{ 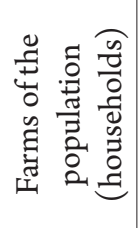 } & \multirow[b]{2}{*}{ 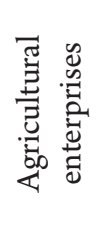 } & \multirow[b]{2}{*}{ 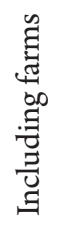 } & \multirow[b]{2}{*}{ 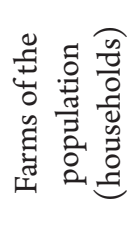 } & \multirow[b]{2}{*}{ Total } & \multicolumn{3}{|c|}{ Including } \\
\hline & & & & & & & & 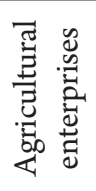 & 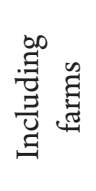 & 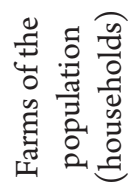 \\
\hline Tractors & 34 & 11 & 66 & 42 & 13 & 58 & 82 & 101 & 104 & 72 \\
\hline Combines & 61 & 22 & 39 & 65 & 24 & 35 & 96 & 101 & 104 & 88 \\
\hline Sowing machines & 33 & 12 & 67 & 35 & 13 & 65 & 96 & 102 & 106 & 94 \\
\hline Plows & 14 & 5 & 86 & 17 & 6 & 83 & 88 & 103 & 107 & 86 \\
\hline Cultivators & 34 & 11 & 66 & 37 & 13 & 63 & 92 & 102 & 105 & 87 \\
\hline Harrows & 31 & 7 & 69 & 32 & 7 & 68 & 96 & 99 & 104 & 94 \\
\hline
\end{tabular}

\section{Conclusions}

Energy capacity used in agriculture of the country in 2017 compared to 2011 decreased by $14.69 \%$. This was mainly due to the reduction in the engine power of tractors, combines and self-propelled vehicles and car engines. Also, working cattle have almost halved in terms of mechanical strength and power of electric motors and electrical installations. It is possible to mention only the increase in capacities of the equipment for production of renewable energy - more than in 10 times.

There is a high dependence of agricultural enterprises on imports of material and technical resources, among them, for example, there are agricultural machinery ( $70 \%$ of imported origin, including combine harvesters - all imported), imported plants (47\% imported, including sugar beets $-90 \%)$, sunflower - 65\%, corn $-70 \%$, rapeseed $-50 \%$ ), plant protection products (due to the moral and technical wear of equipment).

The low intensity of the agricultural sector of Ukraine is largely due to the neglect of the requirements of agricultural machinery and production technology. It is important to apply the required amount of mineral fertilizers, which is one of the important technological requirements for growing crops. Therefore, the effective development of this industry requires a modern, effective and scientifically explained financing program by attracting investment and soft loans.

\section{References:}

Sabluk, P. T. (2011). Realizatsiia mekhanizmu reform v ahrarnii sferi [Implementation of the Reform Mechanism in the Agricultural Sector]. Ekonomika APK, vol. 10, pp. 3-6.

Ofitsiini dani z saitu Derzhavnoi sluzhby statystyky Ukrainy [Official Data from the Website of the State Statistics Service of Ukraine]. Available at: http://www.ukrstat.gov.ua/ (accessed 10 November 2020).

Agrarnye investitcii IFC [IFC Agricultural Investment]. Available at: https://latifundist.com/ spetsproekt/196-agrarnye-investitsii-ifc (accessed 10 November 2020).

Proiekt Kontseptsii Dovhostrokovoi prohramy zabezpechennia ahropromyslovoho kompleksu mineralnymy dobryvamy, v pershu cherhu vitchyznianoho vyrobnytstva, na period do 2020 roku [Draft Concept of the Long-term program of providing the agro-industrial complex with mineral fertilizers, primarily domestic production, for the period up to 2020]. Available at: http://search.ligazakon.ua/ 1_doc2.nsf/link1/NT1366.html (accessed 10 November 2020).

Kushnir, S. (2017). Interdependence of investments and consumer policy: problems and prospects of development. International Scientific Conference Innovative Economy: Processes, Strategies, Technologies: Conference Proceedings, Kielce, Poland: Baltija Publishing, part I.

Pysarenko, T. V., \& Kvasha, T. K. (2019). Stan innovatsiinoi diialnosti ta diialnosti u sferi transferu tekhnolohii v Ukraini u 2018 rotsi: analitychna dovidka [The State of Innovation and Technology Transfer Activities in Ukraine in 2018: Analytical Reference]. Kyiv: UkrINTEI. 